\title{
Soil compaction and cover with black oat on soybean grain yield in lowland under no-tillage system
}

\section{Amauri Nelson Beutler ${ }^{*^{*}}$ (i) Alison Machado Fontinelli ${ }^{1}$ (i) Lucas Santos da Silva ${ }^{1}$ (i) Leandro Galon ${ }^{2}$ (i) Matheus Martins Ferreira ${ }^{3}$ (D) Fernando Sintra Fulaneti ${ }^{3}$ (1)}

${ }^{1}$ Universidade Federal do Pampa (UNIPAMPA), 97650-000, Itaqui, RS, Brasil. E-mail: amauribeutler@unipampa.edu.br. "Corresponding author.

${ }^{2}$ Universidade Federal Fronteira Sul (UFFS), Erechim, RS, Brasil.

${ }^{3}$ Departamento de Fitotecnia, Universidade Federal de Santa Maria (UFSM), Santa Maria, RS, Brasil.

ABSTRACT: Brazil is the largest exporter and second largest producer of soybean grains. Most of this production is from plants grown under no-tillage system (NT). This research evaluated the effect of soil compaction, and different amounts of black oat residues on the soil surface on soybean growth and grain yield in lowland under NT. The experiment was conducted in a completely randomized design with seven treatments and four replications, in the 2016/2017 and 2017/2018 crop seasons. The treatments consisted of: 1) winter fallow without soil compaction $(W F)$; 2) winter fallow with soil compaction $(W F-C)$; 3) black oats and complete removal of surface residues, with soil compaction (OR-C); 4) black oats and removal half of surface residues, with soil compaction (0.5R-C); 5) black oats without surface residue removal, with soil compaction (IR-C); 6) black oats without surface residue removal, plus the residues from treatment 3, with soil compaction (2R-C); 7) black oats without surface residue removal, without soil compaction $(I R)$. When the soybean plants were at the phenological stage R2, they were evaluated nodule, root and shoot dry matter, nitrogen contents, plant height, and grain yield. The soil physical properties were evaluated in the 0.0-0.05, 0.10-0.15 and 0.20-0.25 m layers. The soybean aerial dry matter is $>38 \%$ in non-compacted soil in year with soil water excess, regardless of the amount of surface oat straw. In year with small water deficit, soil with more surface oat straw produced $>5 \%$ shoot dry matter and $>4 \%$ of soybean grain, regardless of compaction. The plant growth and grain yield soybean in lowland varied according to the water conditions, and were affected by soil compaction and amounts of black oats residues on soil surface.

Key words: Glycine max, Avena strigosa, direct seeding.

Compactação do solo e cobertura com aveia preta na produtividade de grãos de soja em várzea sob sistema de plantio direto

\begin{abstract}
RESUMO: O Brasil se destaca na produção de soja, sendo o maior exportador e o segundo maior produtor do grão e a maior parte é cultivado em sistema plantio direto (SPD). Objetivou-se avaliar o efeito da compactação, cultivo e quantidades de palha de aveia preta na superficie do solo sobre o crescimento e o rendimento de grãos de soja em SPD em terras baixas. O delineamento experimental foi inteiramente casualizado com sete tratamentos e quatro repetições. Os tratamentos, nas safras 2016/17 e 2017/18, foram: 1) Pousio no inverno sem compactação $(W F)$; 2) Pousio no inverno + compactação $(W F-C)$; 3) Aveia preta e retirada da palha superficial + compactação (0R-C); 4) Aveia e retirada da metade da palha + compactação $(0,5 R-C) ; 5)$ Aveia + permanência da palhada + compactação (1R-C); 6) Aveia + a palha retirada do tratamento 3 (2 doses palha) + compactação (2R-C); 7) Aveia + permanência da palha, sem compactação (1R). No estádio fenológico R2 a soja foram avaliadas a massa seca de nódulos e de raizes, massa seca e nitrogênio da parte aérea, altura de plantas e produtividade de grãos. No solo foram avaliadas propriedades fisicas nas camadas de 0,0-0,05; 0,10-0,15 e 0,20-0,25 m. A produção de massa seca da parte aérea de soja é > 38\% em solo não compactado em ano com excesso hídrico independente da quantidade de palha de aveia na superficie. Em ano com pequeno déficit hídrico os tratamentos com mais palha produziram $>5 \%$ de massa seca da parte aérea e $>4 \%$ de grãos de soja, independente da compactação. O crescimento e o rendimento de grãos de soja em terras baixas oscilam de acordo com as condições hídricas, sendo influenciada pela compactação e quantidade de palha superficial.

Palavras-chave: Glycine max, Avena strigosa, semeadura direta.
\end{abstract}

\section{INTRODUCTION}

Soybean (Glycine max (L.) Merrill) is the main oilseed produced and consumed in the world, having great food and economic importance. Brazil is the largest exporter and the second largest world producer of soybean grains (FAO, 2018). Soybean crops are usually conducted under no-tillage system (NT) because of its benefits, such as lower implementation costs, soil and water conservation, which are essential for the sustainability of agricultural systems (EMBRAPA, 2013). However, NT can result 
in excessive soil compaction due to machinery traffic on the soil, in special excessive traffic with machines with high weight per axle and under conditions of high water content in soil, decreasing crop growth and grain yield as verified by BOTTA et al. (2010) and GUBIANI et al. (2014)).

Excessive soil compaction results in soil physical degradation, increases soil resistance to penetration and bulk density, and reduces porosity, aeration, water infiltration into the soil and internal water flow reducing nutrients transport in soil. Soil compaction also deforms the root system, and alters carbon cycle and soil biological activity reducing amount of nutrient mineralized from organic matter (NAWAZ et al., 2013), which also decreases crop grain yield (MOALEMI ORE \& KARPARVARFARD, 2008; BOTTA et al., 2010; GUBIANI et al., 2018). SICZEK \& LIPIEC (2011) reported decreases in nodulation and in nitrogen fixation in soybean plants due to compaction, but the use of mulching with crop residues attenuated the detrimental effects of soil compaction.

Soybean crops have been grown in the state of Rio Grande do Sul, Brazil, in rotation with irrigated rice in lowlands. These soils have different dynamics and characteristics when compared to well-drained highlands. Most lowland soils have unfavorable physical characteristics to soybean crops, such as excessive soil compaction, flat relief with drainage deficiency and poor aeration. Additionally, lowland are most susceptible to compaction because remain more wet because deficiency drainage, and the clay type with greater activity and cohesion, sticky when wet and very hard when dry, compared to soil well-drained highlands traditionally used for soybean cultivation. BEUTLER et al. (2014) reported that flooded soil for 16 days at soybean reproductive stage resulted in a decrease of up to $29 \%$ in grain yield. In this context, the use of cover crops, like black oats, improves the soil structure and superficial straw reduce water evaporation when water deficit occurs, mainly in soybean reproductive stage when water demand is greater and water deficit is common.

The objective was to evaluate the effect of soil compaction and amounts of black oat residues on the soil surface in soybean growth and grain yield in lowland under no-tillage system.

\section{MATERIALS AND METHODS}

The experiment was conducted in the $2016 / 2017$ and $2017 / 2018$ crop seasons at the geographic coordinates $29^{\circ} 09^{\prime} 09^{\prime \prime} \mathrm{S}$ and $56^{\circ} 33^{\prime} 03^{\prime \prime}$ $\mathrm{W}$, at $64 \mathrm{~m}$ altitude. The soil was classified as Typic
Ultisol, medium texture, presenting granulometric composition $\left(\mathrm{g} \mathrm{kg}^{-1}\right)$ of 197 clay, 269 silt and 534 sand. The area had a $0.5 \%$ slope. The climate of the region is $\mathrm{Cfa}$, humid subtropical with no defined dry season, and hot summers (PEEL et al., 2007).

The experimental design was completely randomized with seven treatments and four replications, consisting of plots of $2.7 \times 4.0 \mathrm{~m}$. The treatments consisted of: 1) winter fallow with weed control without soil compaction (WF); 2) winter fallow with weed control and soil compaction (WFC); 3) black oats and complete removal of surface residues, with soil compaction (0R-C); 4) black oats and removal of half of surface residues, with soil compaction (0.5R-C); 5) black oats without surface residue removal, with soil compaction (1R-C); 6) black oats without surface residue removal, plus the residues from treatment 3 , with soil compaction (2RC); 7) black oats without surface residue removal, without soil compaction (1R).

The area consisted of a native field, which was limed, chiseling at 0-0.20 m depth, and leveled in September 2015 and remained in fallow. The soil chemical analysis in the 0-0.20 m layer in March 2016 presented: $\mathrm{pH} \mathrm{H}_{2} \mathrm{O}$ of $5.9,6.0 \mathrm{mg} \mathrm{dm}^{-3}$ of $\mathrm{P} ; 0.072$ of $\mathrm{K}, 3.9$ of $\mathrm{Ca}, 1.6$ of $\mathrm{Mg}$; 0.0 of $\mathrm{Al}\left(\mathrm{cmol}_{\mathrm{c}} \mathrm{dm}^{-3}\right)$; base saturation of $73.4 \% ; 1.3 \%$ of organic matter. The organic matter content was determined by the Walkley-Black method; the extractable $\mathrm{P}$ by Mehlich-1; $\mathrm{pH} \mathrm{H}_{2} \mathrm{O}$ in a soil:water solution (1:1); and $\mathrm{K}, \mathrm{Ca}, \mathrm{Mg}$, and $\mathrm{Al}$ as described in TEDESCO et al. (1995).

In May 2016 and 2017, herbicide was applied for weed control and the black oat seeds were sowed in rows spaced $0.17 \mathrm{~m}$ apart, using 80 $\mathrm{kg} \mathrm{ha}^{-1}$ of seeds in all treatments. Soil fertilization consisted of $300 \mathrm{~kg} \mathrm{ha}^{-1}$ of N-P-K fertilizer (5-2020 ); and $100 \mathrm{~kg} \mathrm{ha}^{-1}$ of urea was applied as coverage in all treatments. It was sown throughout all area to equalize the amount of fertilizer in all treatments. In the winter fallow treatments, herbicide was applied at 20 days to kill weed and black oat plants, and at 90 days to control weed plants.

In October, the black oats were cut at $0.03 \mathrm{~m}$ from the soil surface to adjust the amounts of residues in the treatments. The shoot dry matter was $8 \mathrm{Mg} \mathrm{ha}^{-1}$ in 2016 and $7 \mathrm{Mg} \mathrm{ha}^{-1}$ in 2017, with $1.0 \%$ $\mathrm{N}$ in dry biomass. Soil compaction in treatments 2 to 6 was carried out after the amounts of residues were established, on 11/07/2016, using a tractor with weight of $11 \mathrm{Mg}$ and four same width and pressure tires for one side-by-side passing over the entire soil surface, twice; the soil water content was at field capacity. The compaction was performed only at the 2016 year. 
In the first half of November, soybean seeds of the cultivars Bmx Magna RR (2016) and NS 6601 IPRO (2017) were treated, inoculated, and sown in all plots, using a fertilizer sowing-machine with shank furrower; the sowing rows were spaced $0.45 \mathrm{~m}$ apart, with 16 seeds per meter, and were arranged transversally to the soil compaction. The soil was fertilized according to recommendations of the CQFS (2016). Drains were made on the sides of the experimental plots to remove excess water since the area had a flat relief, groundwater near the soil surface, and slow drainage.

In February 2017 and 2018, when the soybean plants were at the R2 stage, 28 samples were taken with a $0.3 \times 0.3 \times 0.15 \mathrm{~m}$ deep metal box, placing the soybean row in the center of the square, with 4 to 5 plants. These samples were used to evaluate the nodule, root dry matter, and nitrogen contents in the shoot dry matter. Nitrogen was determined using two sub-determinations in laboratory by the Kjeldahl method. The plant heights on 0.5 linear meters and shoot dry matter on $0.25 \mathrm{~m}^{2}$ were also evaluated. The 100 -grain weight and grain yield of the plants were evaluated after harvesting in areas of $6 \mathrm{~m}^{2}$ per plot in 2018; in 2017 grain yield was not evaluated due to intense and sudden attack of soy bugs from adjacent areas that decimated the experiment in few days in grain filled phase. The grain moisture was adjusted to $13 \%$. It was not possible to evaluate the soybean grain yield in the first crop season.

The soil physical analysis was carried out using a completely randomized design, in a $7 \times 3$ factorial arrangement consisting of seven treatments and three depths, with six replications.

In December 2016 and 2017, soil cylinders with height of $0.03 \mathrm{~m}$ and diameter of $0.05 \mathrm{~m}$ were collected in the $0.0-0.05,0.10-0.15$, and $0.20-0.25$ $\mathrm{m}$ soil layers, between the soybean rows. The soil cylinders were placed in a tray containing $0.02 \mathrm{~m}$ water depth for $24 \mathrm{~h}$ for saturation by capillarity, weighed, and subjected to $0.006 \mathrm{MPa}$ stress in Richard pressure chambers for microporosity determination (FLINT \& FLINT, 2002). Soil dry weight and bulk density (BD) were determined after $24 \mathrm{~h}$ in an oven at $105{ }^{\circ} \mathrm{C}$. Total porosity was determined according to FLINT \& FLINT (2002), and macroporosity by the difference between total porosity and microporosity.

The maximum $\mathrm{BD}$ was determined by the Proctor test, with reuse of material from deformed samples collected in the $0.0-0.20 \mathrm{~m}$ soil layer and passed through a $0.04 \mathrm{~m}$ mesh sieve; the Proctor test was performed by three soil layers added to a cylinder, each receiving 25 socket stroke of $2.5 \mathrm{~kg}$ failing from
$0.3 \mathrm{~m}$ height, corresponding to compaction energy of $60.2 \mathrm{~kJ} \mathrm{~m}^{-3}$; the maximum bulk density was 1.90 $\mathrm{g} \mathrm{cm}^{-3}$, and the optimum moisture of compaction was $12.4 \%$. The bulk relative density (BDr) was evaluated, which consisted of dividing the $\mathrm{BD}$ found by the maximum BD.

The results were subjected to analysis of variance and, when the results were significant, the Scott-Knott test at 5\% probability of error was applied to compare the means.

\section{RESULTS AND DISCUSSION}

In the 2016/2017 crop season, rainfall was more regular, and there was excess water in the first half of January and February (Figure 1A). This left the soil with high water content, and close to saturation for several days, since the soil presents flat relief, groundwater near the soil surface, and slow drainage. In the 2017/2018 crop season, there were periods with little rainfall (Figure 1B) causing a water deficit in the soil, especially in February and early March (25 days), which is a critical period for soybean grain filling.

The interaction between treatments and soil layers was not significant for the soil physical properties. BD was higher in treatments with additional soil compaction, regardless of the amount of black oat residues on soil surface, in the 2016/2017 crop season (Table 1).

However, in the 2017/2018 crop season, the $2 \mathrm{R}-\mathrm{C}$ treatment presented equal $\mathrm{BD}$ to the noncompacted treatments, denoting the positive effects of large amounts of black oat residues (16 and $14 \mathrm{Mg} \mathrm{ha}^{-1}$ straw in 2016/17 and 2017/18, respectively) on soil restructuration and $\mathrm{BD}$ reduction, since in the second year was not additional compaction. Considering the differences between treatments $1 \mathrm{R}-\mathrm{C}$ and $1 \mathrm{R}$, the two years of black oat and soybean crops in no-tillage system (NT) were not enough to restructure the soil and reduce $\mathrm{BD}$ in $1 \mathrm{R}-\mathrm{C}$, nor increase $\mathrm{BD}$ in $1 \mathrm{R}$. According to GUBIANI et al. (2018), tillage reduces $\mathrm{BD}$ and increases porosity in the soil surface layer; according to SILVA et al. (2012), this effect decreases over time and remains less than a year because of the restructuring and natural densification of the soil.

This explains why BD of the treatment 1R did not increase: the soil was subsoiled and harrowed in 2015, which was one year before starting the experiment in NT with and without additional machinery traffic. In the treatment $1 \mathrm{R}-\mathrm{C}$, the soil compaction and higher $\mathrm{BD}$ due to additional machinery traffic were not attenuated throughout 


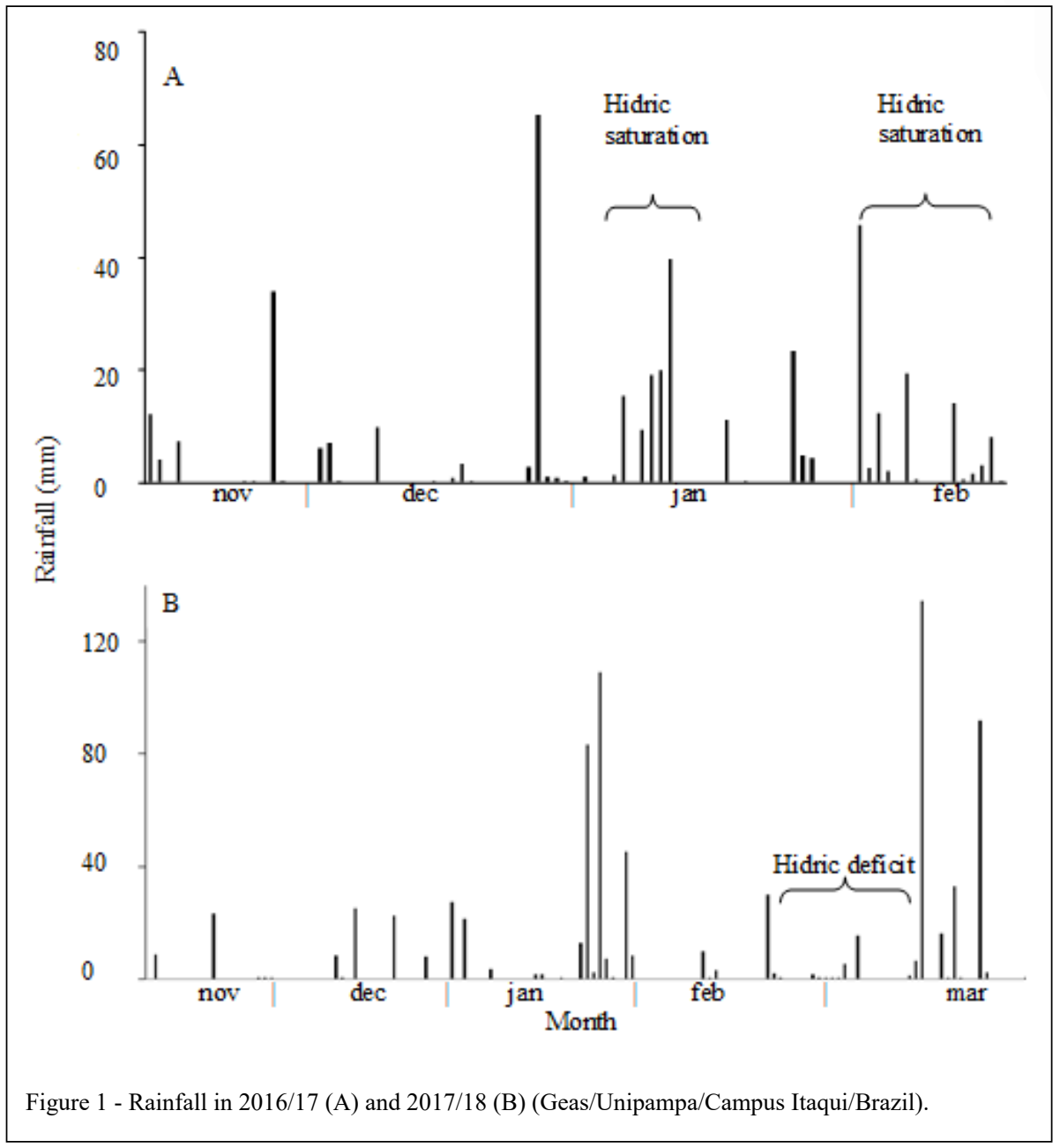

the two years of crops with inclusion of only black oats in winter.

BD was lower in the $0-0.05 \mathrm{~m}$ layer than in the $0.10-0.15$ and $0.20-0.25 \mathrm{~m}$ soil layers in all treatments, possibly because of the decompaction effect of the furrower of the fertilizer seeder in the two annual seeding operations in this layer, increasing total porosity and macro or microporosity. Moreover, high $\mathrm{BD}$ values were reported in the $0.10-0.15$ and 0.20-0.25 m layers, considering that the soil had $20 \%$ clay, resulting in relative bulk density (BDr) above 0.90 . The BDr above 0.90 , combined with excess water in the 2016/2017 crop season, resulted in lower plant heights and shoot dry matter (Table 2). In the 2017/2018 crop season, which presented water deficit, $\mathrm{BDr}$ up to 0.92 resulted in higher soybean grain yield, which was more related to amount of black oat residues on the soil surface than to soil compaction. SANTOS et al. (2019) found in clayey Oxisol under
NT for 15 years that chiseling and descompaction did not increase soybean grain yield in years with good rain distribution.

In the 2016/2017 crop season, the plant height and soybean shoot dry matter were more than $22 \%$ higher in the treatments WF and $1 \mathrm{R}$, which had no additional compaction by machinery traffic (Table 2). Shoot dry matter is directly related to grain filling. The treatments WF and $1 \mathrm{R}$ would probably have higher grain yield, considering the relation between shoot dry weight and grain yield, when comparing treatments with the same cultivar. This was reported in the 2017/2018 crop season, with correlation of 0.88 between shoot dry matter and grain yield. GUBIANI et al. (2018) reported a correlation of 0.97 between shoot dry matter and grain yield of soybean plants grown in lowlands soils with drainage problems.

The soybean shoot dry matter is dependent on plant height, which is a genetic trait and may 
Table 1 - Bulk density (BD), relative bulk density (BDr), total porosity, macro and microporosity in treatments and layers in December of 2016 and 2017.

\begin{tabular}{|c|c|c|c|c|c|}
\hline Treatments & Bulk density & BDr & Total porosity & Macroporosity & Microporosity \\
\hline & $\left(\mathrm{g} \mathrm{cm}^{-3}\right)$ & \multicolumn{4}{|c|}{ 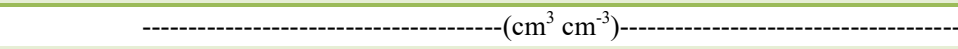 } \\
\hline \multicolumn{6}{|c|}{ - } \\
\hline WF & $1.71 \mathrm{~b}$ & 0.90 & $0.39 \mathrm{a}$ & $0.11 \mathrm{a}$ & $0.27 \mathrm{~b}$ \\
\hline WF-C & $1.77 \mathrm{a}$ & 0.93 & $0.37 \mathrm{~b}$ & $0.09 \mathrm{~b}$ & $0.27 \mathrm{~b}$ \\
\hline 0R-C & $1.77 \mathrm{a}$ & 0.93 & $0.36 \mathrm{~b}$ & $0.09 \mathrm{~b}$ & $0.27 \mathrm{~b}$ \\
\hline $0.5 \mathrm{R}-\mathrm{C}$ & $1.80 \mathrm{a}$ & 0.95 & $0.35 \mathrm{~b}$ & $0.07 \mathrm{c}$ & $0.28 \mathrm{a}$ \\
\hline 1R-C & $1.77 \mathrm{a}$ & 0.93 & $0.35 \mathrm{~b}$ & $0.07 \mathrm{c}$ & $0.28 \mathrm{a}$ \\
\hline 2R-C & $1.75 \mathrm{a}$ & 0.92 & $0.36 \mathrm{~b}$ & $0.07 \mathrm{c}$ & $0.29 \mathrm{a}$ \\
\hline $1 \mathrm{R}$ & $1.69 \mathrm{~b}$ & 0.89 & $0.37 \mathrm{~b}$ & $0.08 \mathrm{~b}$ & $0.29 \mathrm{a}$ \\
\hline \multicolumn{6}{|c|}{ 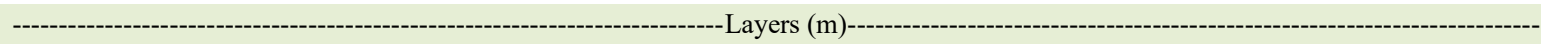 } \\
\hline $0-0.05$ & $1.70 \mathrm{~b}$ & 0.89 & $0.38 \mathrm{a}$ & $0.09 \mathrm{a}$ & $0.29 \mathrm{a}$ \\
\hline $0.10-0.15$ & $1.78 \mathrm{a}$ & 0.94 & $0.36 \mathrm{~b}$ & $0.08 \mathrm{a}$ & $0.28 \mathrm{~b}$ \\
\hline $0.20-0.25$ & $1.78 \mathrm{a}$ & 0.94 & $0.36 \mathrm{~b}$ & $0.09 \mathrm{a}$ & $0.27 \mathrm{~b}$ \\
\hline \multicolumn{6}{|c|}{ 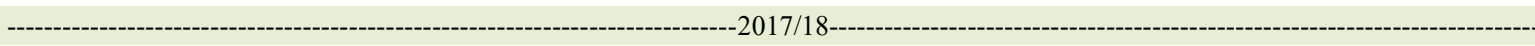 } \\
\hline WF & $1.72 \mathrm{~b}$ & 0.91 & $0.37 \mathrm{~b}$ & $0.10 \mathrm{a}$ & $0.28 \mathrm{~d}$ \\
\hline WF-C & $1.73 \mathrm{a}$ & 0.91 & $0.37 \mathrm{~b}$ & $0.10 \mathrm{a}$ & $0.27 \mathrm{~d}$ \\
\hline 0R-C & $1.77 \mathrm{a}$ & 0.93 & $0.35 \mathrm{~b}$ & $0.07 \mathrm{~b}$ & $0.29 \mathrm{c}$ \\
\hline $0.5 \mathrm{R}-\mathrm{C}$ & $1.76 \mathrm{a}$ & 0.93 & $0.36 \mathrm{~b}$ & $0.08 \mathrm{~b}$ & $0.28 \mathrm{~d}$ \\
\hline 1R-C & $1.75 \mathrm{a}$ & 0.92 & $0.37 \mathrm{~b}$ & $0.08 \mathrm{~b}$ & $0.29 \mathrm{c}$ \\
\hline 2R-C & $1.72 \mathrm{~b}$ & 0.91 & $0.38 \mathrm{~b}$ & $0.07 \mathrm{~b}$ & $0.30 \mathrm{~b}$ \\
\hline $1 \mathrm{R}$ & $1.68 \mathrm{~b}$ & 0.88 & $0.41 \mathrm{a}$ & $0.08 \mathrm{~b}$ & $0.32 \mathrm{a}$ \\
\hline \multicolumn{6}{|c|}{ 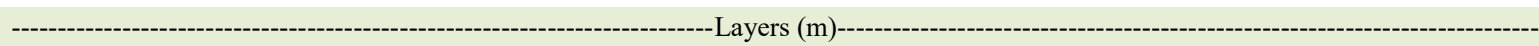 } \\
\hline $0-0.05$ & $1.68 \mathrm{~b}$ & 0.88 & $0.39 \mathrm{a}$ & $0.10 \mathrm{a}$ & $0.29 \mathrm{a}$ \\
\hline $0.10-0.15$ & $1.75 \mathrm{a}$ & 0.92 & $0.37 \mathrm{~b}$ & $0.07 \mathrm{~b}$ & $0.30 \mathrm{a}$ \\
\hline $0.20-0.25$ & $1.76 \mathrm{a}$ & 0.93 & $0.36 \mathrm{~b}$ & $0.07 \mathrm{~b}$ & $0.28 \mathrm{~b}$ \\
\hline
\end{tabular}

Averages followed by lowercase letters in the column not differ from one another (Scott-Knott test, $\mathrm{P} \leq 0.05)$. There was no interaction treatment $\mathrm{x}$ layer. Winter fallow without soil compaction (WF); winter fallow with soil compaction (WF-C); black oats and complete removal of surface residues, with soil compaction (0R-C); black oats and removal of half of surface residues, with soil compaction $(0.5 \mathrm{R}-\mathrm{C})$; black oats without surface residue removal, with soil compaction (1R-C); black oats without surface residue removal, plus the residues from treatment 3 , with soil compaction (2R-C); black oats without surface residue removal, without soil compaction (1R).

vary according to edaphoclimatic conditions and cultural practices (TORRES et al., 2015). The excess rainfall in the first half of January and February 2017 hindered the soybean plant growth in treatments with additional soil compaction, which presented higher $\mathrm{BD}$; this considering that the plants were grown in a soil with flat relief, groundwater near the soil surface, and low total porosity and macroporosity, which are responsible for drainage and aeration. Similar results were found by GUBIANI et al. (2018), who reported that the soybean plants grown in compacted soil under NT had lower shoot dry weight and grain yield than those grown in less compacted soils under conventional tillage system, in a year with frequent rainfall, in lowlands. The authors attributed this result to oxygen deficit in the NT due to the slow drainage of this soil. Soil compaction results in low plant growth by reducing soil aeration and water and nutrient absorption from the soil (CALONEGO et al., 2011). According to SCHÖFFEL et al. (2001), lowlands are characterized by poor drainage and, in times of frequent rainfall, their soil saturation is rapidly reached, which may cause negative effects on plant growth because of the stress caused by water saturation. Thus, soil compaction, combined with soil water saturation, reduces oxygen availability to the roots, impairing their growth and activity.

The 2016/2017 crop season presented a higher root dry matter in the WF-C treatment, in the $0-0.15 \mathrm{~m}$ soil layer; this was probably a response to soil compaction to supply the plant needs for water, air, and nutrients. This root dry matter in WF-C in 
0-0.15 m layer possibly occurred due the absence of plants in winter because they were controlled with herbicides compared to others compacted treatments where oat was cultivated; this because oats roots create biopores and galleries in soil, which remain after roots decomposition allowing greater soybean roots growth in depth by galleries and improving soil structure, although it was not enough to reduce soil density; there is also additional effect of oat straw on soil surface that keeps soil more wet and reduce resistance to root growth in depth.

According to MOALEMI ORE \& KARPARVARFARD (2008), soil compaction prevents the passage of roots, which compensates this effect by lateral expansion of roots through points of lower soil resistance; this possibly occurred in the treatment WF-C, which had additional compaction and no plant residues on the soil surface. The nodule dry weight and nitrogen content in the shoot dry matter were not affected by soil compaction and amount of black oat residues on the soil surface.

In the 2016/2017 crop season, which presented excess rainfall, black oat residues on the soil surface had no effect on the soybean plant growth, but the additional soil compaction was harmful. In the 2017/2018 crop season, differences in plant height and shoot dry matter between treatments were smaller compared to the previous crop season; treatments with higher shoot dry matter had higher grain yields, with a correlation of 0.88 (Table 2).

In the 2017/2018 crop season, which presented a 25-day water deficit in late February and early March, the results were opposite when compared to the previous crop. The amount of black oat residues on the soil surface presented benefits, and the additional soil compaction had little effect on the variables. Thus, treatments with plant residues on the soil surface $>7 \mathrm{Mg} \mathrm{ha}^{-1}$ (1R-C, 2R-C, and $1 \mathrm{R})$ presented higher soybean grain yield than those without plant residues (WF, WF-C, OR-C) or with half of the black oat residues $(0.5 \mathrm{R}-\mathrm{C})$ on the soil surface. Grain yield was $9 \%$ higher in the treatment $1 \mathrm{R}$ compared to WF due to the growth of black oat and its residues on the soil. This occurred probably because the residues on the soil surface formed a physical barrier, reducing the soil temperature and

Table 2 - Plant height, shoot dry matter, roots and nodules, and nitrogen in shoot dry matter of soybean in full flowering (R2), in $2016 / 17 / 18$, and more grain yield and mass of 100 grains in 2017/18.

\begin{tabular}{|c|c|c|c|c|c|c|c|}
\hline Treatments & Plant height & $\begin{array}{l}\text { Shoot dry } \\
\text { matter }\end{array}$ & Root dry matter & Root nodules & $\begin{array}{l}\text { Nitrogen in } \\
\text { dry matter }\end{array}$ & Grain yield & $\begin{array}{c}\text { Mass of } 100 \\
\text { grain }\end{array}$ \\
\hline & $(\mathrm{cm})$ & $\left(\mathrm{Mg} \mathrm{ha}^{-1}\right)$ & \multicolumn{2}{|c|}{-------(g) (0.30x0.30x0.15 m)------ } & $(\%)$ & $\left(\mathrm{Mg} \mathrm{ha}^{-1}\right)$ & (g) \\
\hline \multicolumn{8}{|c|}{ } \\
\hline WF & $102 \mathrm{a}$ & 10,315 a & $24 \mathrm{~b}$ & $6.7^{\mathrm{ns}}$ & $2.4^{\mathrm{ns}}$ & - & - \\
\hline WF-C & $68 \mathrm{c}$ & $5,201 \mathrm{~b}$ & $34 \mathrm{a}$ & 4.4 & 2.3 & - & - \\
\hline OR-C & $63 \mathrm{~d}$ & $5,728 \mathrm{~b}$ & $21 \mathrm{~b}$ & 6.0 & 2.8 & & \\
\hline $0.5 \mathrm{R}-\mathrm{C}$ & $69 \mathrm{c}$ & $5,978 \mathrm{~b}$ & $20 \mathrm{~b}$ & 5.8 & 2.5 & - & - \\
\hline 1R-C & $80 \mathrm{~b}$ & $7,046 \mathrm{~b}$ & $19 \mathrm{~b}$ & 7.1 & 2.9 & - & - \\
\hline 2R-C & $75 \mathrm{~b}$ & $6,499 \mathrm{~b}$ & $19 \mathrm{~b}$ & 5.4 & 3.0 & - & - \\
\hline $1 \mathrm{R}$ & $110 \mathrm{a}$ & $9,711 \mathrm{a}$ & $22 \mathrm{~b}$ & 6.6 & 2.5 & - & - \\
\hline \multicolumn{8}{|c|}{ } \\
\hline WF & $101 \mathrm{a}$ & $6,197 b$ & $18 \mathrm{a}$ & $3.0 \mathrm{~b}$ & $3.0 \mathrm{a}$ & $2,976 \mathrm{~b}$ & $14.4^{\mathrm{ns}}$ \\
\hline WF-C & $97 \mathrm{a}$ & $6,420 \mathrm{~b}$ & $21 \mathrm{a}$ & $3.6 \mathrm{~b}$ & $2.9 \mathrm{a}$ & $2,753 \mathrm{~b}$ & 14.7 \\
\hline OR-C & $85 \mathrm{c}$ & $5,402 \mathrm{~b}$ & $18 \mathrm{a}$ & $4.0 \mathrm{a}$ & $3.0 \mathrm{a}$ & $2,731 \mathrm{~b}$ & 15.1 \\
\hline $0.5 \mathrm{R}-\mathrm{C}$ & $89 \mathrm{~b}$ & $5,620 \mathrm{~b}$ & $19 \mathrm{a}$ & $4.1 \mathrm{a}$ & $3.0 \mathrm{a}$ & $2,873 \mathrm{~b}$ & 15.0 \\
\hline 1R-C & $97 \mathrm{a}$ & 7,499 a & $20 \mathrm{a}$ & $4.5 \mathrm{a}$ & $2.8 \mathrm{a}$ & $3,234 \mathrm{a}$ & 14.4 \\
\hline 2R-C & $98 \mathrm{a}$ & 6,753 a & $16 \mathrm{~b}$ & $4.4 \mathrm{a}$ & $2.8 \mathrm{a}$ & $3,097 \mathrm{a}$ & 14.7 \\
\hline $1 \mathrm{R}$ & $100 \mathrm{a}$ & $7,411 \mathrm{a}$ & $16 \mathrm{~b}$ & $3.4 \mathrm{~b}$ & $2.4 \mathrm{~b}$ & $3,251 \mathrm{a}$ & 14.4 \\
\hline
\end{tabular}

Averages followed by lowercase letters in column not differ from one another (Scott-Knott test, P $\leq 0.05$ ). ${ }^{\text {ns Not }}$ significant. - Not determined. Winter fallow without soil compaction (WF); winter fallow with soil compaction (WF-C); black oats and complete removal of surface residues, with soil compaction (0R-C); black oats and removal of half of surface residues, with soil compaction (0.5R-C); black oats without surface residue removal, with soil compaction (1R-C); black oats without surface residue removal, plus the residues from treatment 3, with soil compaction (2R-C); black oats without surface residue removal, without soil compaction (1R). 
water evaporation and; consequently, allowing a higher soil water content when compared to the treatments without residues. According to RIBEIRO et al. (2016), a cohesive soil managed in NT with millet mulch residues and soybean crops has higher moisture compared to that in conventional tillage. ROSIM et al. (2012) found higher soil water content in the $0-0.10,0.10-0.20$ and $0.20-0.30 \mathrm{~m}$ layers with the use of 5 and $10 \mathrm{Mg} \mathrm{ha}^{-1}$ of millet residues on the soil surface when compared to soils without residues.

Moreover, BALBINOT JUNIOR et al. (2017) evaluated a Typic Hapludox and found that the use of residues of Brachiaria sp. on the soil surface did not present higher soybean grain yield compared to fallow soil; however, the treatment with root system plus surface residues or with root system without residues of the aerial part provided soybean grain yields $22 \%$ higher than the fallow area. This indicated that the root system of cover crops can increase soybean grain yield, probably due to biopores and galleries remained in soil after roots decomposition enabling better soybean roots growth in depth, nutrient recycling, by relocating nutrients back to the topsoil, or even by increasing $\mathrm{P}$ availability in the soil layers explored by soybean roots.

Therefore, in addition to these benefitshigher water availability and lower thermal amplitudeto soils, the use of black oat can improve nutrient cycling and availability. According to CAIRES et al. (2006), the use of black oat as cover crop increases $\mathrm{N}$ and $\mathrm{P}$ contents in the shoot dry matter of soybean plants grown in the following crop season.

Comparing NT with soil compaction to NT without soil compaction $(1 \mathrm{R}-\mathrm{C} \times 1 \mathrm{R})$, soybean grain yield presented no differences, indicating that the additional soil compaction was not the limiting factor in the 2017/2018 crop season. This possibly occurred because the additional compaction occurred more than a year ago and resulting in small variations in the soil physical properties (BD, total porosity and macroporosity) between the two treatments in 2017/18 soybean cultivation; yet, all oat straw remained on soil surface reducing surface temperature and water evaporation, mitigating the effect of the water deficit occurred in February 2018, soybean grain filling period. In addition, it appears that soybean yield was close to $3 \mathrm{Mg} \mathrm{ha}^{-1}$ indicating that the water deficit was small.

\section{CONCLUSION}

In lowland, the soybean crop presented $22 \%$ higher plant height and shoot dry matter in the treatments without additional soil compaction in the 2016/2017 crop season, when excessive rain occurred, regardless of the amount of black oat residues on the soil surface. In the 2017/2018 crop season, when water deficit occurred, the highest shoot dry matter and soybean grain yield were reported in treatments with use of black oat residues on the soil surface, regardless of soil compaction.

\section{ACKNOWLEDGEMENTS}

We would like to thank the Conselho Nacional de Desenvolvimento Científico e Tecnológico (CNPq) for granting a scholarship and Coordenação de Aperfeiçoamento de Pessoal de Nível Superior (CAPES), Brasil, by financed in part the study.

\section{DECLARATION OF CONFLICT OF} INTEREST

The authors declare no conflict of interest. The founding sponsors had no role in the design of the study; in the collection, analyses, or interpretation of data; in the writing of the manuscript, and in the decision to publish the results.

\section{AUTHORS' CONTRIBUTIONS}

All authors contributed equally to the design and writing of the manuscript. All authors critically reviewed the manuscript and approved the final version.

\section{REFERENCES}

BALBINOT JUNIOR, A. A. et al. Contribution of roots and shoots of Brachiaria species to soybean performance in succession. Pesquisa Agropecuária Brasileira, v.52, p.592-598, 2017. Available from: $<$ https://www.scielo.br/pdf/pab/v52n8/1678-3921pab-52-08-00592.pdf $>$. Accessed: Oct. 06, 2020. doi: 10.1590/ s0100-204x2017000800004.

BEUTLER, A .N. et al. Soil hydric excess and soybean yield and development in Brazil. Australian Journal of Crop Science, v.8, p.1461-1466, 2014. Available from: <http://www.cropj.com/ beutler_8_10_2014_1461_1466.pdf >. Accessed: Oct. 06, 2020.

BOTTA, G. F. et al. Tillage and traffic effects (planters and tractors) on soil compaction and soybean (Glycine max L.) yields in Argentinean pampas. Soil \& Tillage Research, v.110, p.167-174, 2010. Available from: <https://www.sciencedirect.com/science/ article/pii/S0167198710001157>. Accessed: Oct. 06, 2020. doi: 10.1016/j.still.2010.07.001.

CAIRES, E. F. et al. Surface application of lime ameliorates subsoil acidity and improves root growth and yield of wheat in an acid soil under no-till system. Scientia Agricola, v.63, p.502-509, 2006. Available from: <https://www.scielo.br/pdf/sa/v63n5/31412.pdf $>$. Accessed: Oct. 06, 2020. doi: 10.1590/S0103-90162006000500013.

CALONEGO, J. C. et al. Cover crops growth in compacted soil. Bioscience Journal, v.27, p.289-296, 2011. Available from: $<$ http://www.seer.ufu.br/index.php/biosciencejournal/article/ view/7632/7235>. Accessed: Oct. 06, 2020. 
CQFS - Comissão de química e fertilidade do solo. Manual de adubação e de calagem para os Estados do Rio Grande do Sul e Santa Catarina. 11 ed. Porto Alegre: Sociedade Brasileira de Ciência do Solo, 2016. 376p.

EMBRAPA - Empresa brasileira de pesquisa agropecuária Sistemas de preparo do solo: trinta anos de pesquisas na Embrapa Soja. Londrina: Embrapa Soja, 2013. 72p.

FAO - Food and agriculture organization of the united nations. Crops. 2018. Available from: <http://www.fao.org/faostat/ en/\#data/QC>. Accessed: Sep. 28, 2020.

FLINT, L. E.; FLINT, A. L. Porosity. In: DANE, J. H.; TOPP, G. C. Methods of soil analysis: physical methods. Madison: Soil Science Society America, 2002. Part. 4. p.241-254.

GUBIANI, P. I. et al Interaction between water availability and soil compaction on common bean growth and yield. Revista Brasileira de Ciência do Solo, v.38, p.765-733, 2014. Available from: <https://www.scielo.br/pdf/rbcs/v38n3/08.pdf $>$. Accessed: Oct. 06, 2020. doi: 10.1590/S0100-

GUBIANI, P. I. et al. Transpiration reduction factor and soybean yield in low land soil with ridge and chiseling. Revista Brasileira de Ciência do Solo, v.42, p.e0170282, 2018. Available from: <https:// www.scielo.br/pdf/rbcs/v42/0100-0683-rbcs-42-e0170282.pdf $>$. Accessed: Oct. 06, 2020. doi: 10.1590/18069657rbcs20170282.

MOALEMI ORE, A.; KARPARVARFARD, S. H. Effects of soil compaction due to wheel traffic on corn growth and yield. Journal of Water and Soil Science, v.11, p.579-594, 2008. Available from: $<$ https://www.researchgate.net/publication/26622205 Effects of_Soil_Compaction_Due_to_Wheel_Traffic_on_Corn_Growth_ and Yield $>$. Accessed: Oct. 06, 2020.

NAWAZ, M. F. et al. Soil compaction impact and modelling A review. Agronomy for Sustainable Development, v.33, p.291-309, 2013. Available from: <https://link.springer.com/ article/10.1007/s13593-011-0071-8>. Accessed: Oct. 06, 2020. doi: $10.1007 / \mathrm{s} 13593-011-0071-8$.

PEEL, M. C. et al. Updated world map of the Köppen-Geiger climate classification. Hydrology and Earth Systems Sciences, v.11, p.1633-1644, 2007. Available from: <https://hess.copernicus. org/articles/11/1633/2007/>. Accessed: Oct. 06, 2020. doi: 10.5194/hess-11-1633-2007.
RIBEIRO, L. S. et al. Spatial variability of physical attributes of a cohesive soil under conventional and no-tillage management systems. Pesquisa Agropecuária Brasileira, v.51, p.16991702, 2016. Available from: <https:/www.scielo.br/pdf/pab/ v51n9/0100-204X-pab-51-09-1699.pdf>. Accessed: Oct. 06, 2020. doi: 10.1590/s0100-204x2016000900071.

ROSIM, D. C. et al. Soil compaction in a Rhodic hapludox soil as influenced by straw management and quantity on surface. Bragantia, v.71, p.502-508, 2012. Available from: $<$ https://www. scielo.br/pdf/brag/v71n4/aop 1535 12.pdf\%20>. Accessed: Oct. 06, 2020. doi: 10.1590/S0006-87052013005000003.

SANTOS, E. L. et al. Chiseling and gypsum application affecting soil physical attributes, root growth and soybean yield. Revista Ciência Agronômica, v.50, p.536-542, 2019. Available from: <https://www.scielo.br/pdf/rca/v50n4/18066690-rca-50-04-0536.pdf >. Accessed: Oct. 06, 2020. doi: $10.5935 / 1806-6690.20190063$

SCHÖFFEL, E. R. et al. Hidrical excess on yield components in soybeans. Ciência Rural, v.31, p.7-12, 2001. Available from: $<$ https://www.scielo.br/pdf/cr/v31n1/a02v31n1.pdf $>$. Accessed: Oct. 06, 2020. doi: 10.1590/S0103-84782001000100002.

SICZEK, A.; LIPIEC, J. Soybean nodulation and nitrogen fixation in response to soil compaction and surface straw mulching. Soil \& Tillage Research, v.114, p.50-56, 2011. Available from: <https://www.sciencedirect.com/science/article/ pii/S0167198711000791>. Accessed: Oct. 06, 2020. doi: 10.1016/j. still.2011.04.001.

SILVA, S. G. C. et al. Temporary effect of chiseling on the compaction of a Rhodic Hapludox under no-tillage. Revista Brasileira de Ciência do Solo, v.36, p.547-555, 2012. Available from: <https:// www.scielo.br/pdf/rbcs/v36n2/a24v36n2.pdf >. Accessed: Oct. 06, 2020. doi: 10.1590/S0100-06832012000200024.

TEDESCO, M. J. et al. Análises de solo, plantas e outros materiais. 2 ed. Porto Alegre: Departamento de Solos, Universidade Federal do Rio Grande do Sul, 1995. 174 p. (Boletim técnico, 5)

TORRES, F. E. et al. Agronomic performance and genetic dissimilarity between soybean genotypes. Revista de Ciências Agrárias, v.38, p.111-117, 2015. Available from: <http://www.scielo.mec.pt/pdf/ rca/v38n1/v38n1a16.pdf>. Accessed: Oct. 06, 2020. 